\title{
Saccharomyces cerevisiae RAD5-Encoded DNA Repair Protein Contains DNA Helicase and Zinc-Binding Sequence Motifs and Affects the Stability of Simple Repetitive Sequences in the Genome
}

\author{
ROBERT E. JOHNSON, ${ }^{1}$ SAMUEL T. HENDERSON, ${ }^{2}$ THOMAS D. PETES, ${ }^{3}$ SATYA PRAKASH, ${ }^{4}$ \\ MICHAEL BANKMANN, ${ }^{1}$ AND LOUISE PRAKASH ${ }^{1 *}$ \\ Department of Biophysics, University of Rochester School of Medicine, Rochester, New York 14642 ${ }^{1}$; \\ Department of Molecular Genetics and Cell Biology, University of Chicago, Chicago, Illinois 60637'; \\ Department of Biology, University of North Carolina, Chapel Hill, North Carolina 27599-3280 ${ }^{3}$; \\ and Department of Biology, University of Rochester, Rochester, New York $14627^{4}$
}

Received 13 April 1992/Returned for modification 19 May 1992/Accepted 10 June 1992

\begin{abstract}
rad5 (rev2) mutants of Saccharomyces cerevisiae are sensitive to UV light and other DNA-damaging agents, and $R A D 5$ is in the $R A D 6$ epistasis group of DNA repair genes. To unambiguously define the function of $R A D 5$, we have cloned the $R A D 5$ gene, determined the effects of the rad5 deletion mutation on DNA repair, DNA damage-induced mutagenesis, and other cellular processes, and analyzed the sequence of $R A D 5$-encoded protein. Our genetic studies indicate that $R A D 5$ functions primarily with $R A D 18$ in error-free postreplication repair. We also show that $R A D 5$ afiects the rate of instability of poly(GT) repeat sequences. Genomic poly(GT) sequences normally change length at a rate of about $10^{-4}$; this rate is approximately 10 -fold lower in the rad5 deletion mutant than in the corresponding isogenic wild-type strain. $R A D 5$ encodes a protein of 1,169 amino acids of $M_{r}$ 134,000, and it contains several interesting sequence motifs. All seven conserved domains found associated with DNA helicases are present in RAD5. RAD5 also contains a cysteine-rich sequence motif that resembles the corresponding sequences found in 11 other proteins, including those encoded by the DNA repair gene $R A D 18$ and the $R A G 1$ gene required for immunoglobin gene arrangement. A leucine zipper motif preceded by a basic region is also present in RAD5. The cysteine-rich region may coordinate the binding of zinc; this region and the basic segment might constitute distinct DNA-binding domains in RAD5. Possible roles of RAD5 putative ATPase/DNA helicase activity in DNA repair and in the maintenance of wild-type rates of instability of simple repetitive sequences are discussed.
\end{abstract}

DNA containing pyrimidine dimers and other types of UV damage is a poor template for the replication machinery. Since DNA polymerases cannot copy past such damage, a gap ensues in the newly synthesized strand across from the damage site. This gap can be filled in by several different postreplication repair processes. Genetic evidence from Saccharomyces cerevisiae suggests that the majority of gaps are filled in an error-free manner in which information for gap filling is obtained from the undamaged strand in the sister duplex (45). Either recombinational or nonrecombinational mechanisms may be utilized. In recombination, the strand from the sister duplex fills in the gap; a nonrecombinational mechanism might entail a copy choice type of DNA synthesis in which blocked DNA polymerase switches from the damaged template, carries out translesion DNA synthesis by copying the undamaged strand in the sister duplex, and then switches back to the damaged template after clearing the lesion. Under certain circumstances, gap filling can occur by mutagenic bypass of the lesion.

To elucidate the mechanisms employed by eukaryotic cells to fill in the gap across from the lesion, we have been studying the genes that function in nonmutagenic and mutagenic postreplication repair pathways in $S$. cerevisiae. Several of these genes have been cloned, and in some cases, their protein products have been purified and their biochemical activities have been identified; in other instances, the

\footnotetext{
* Corresponding author.
}

activities of proteins encoded by some of these genes have been inferred from their sequences. Among the genes required for postreplication repair, $R A D 6$ has the most pleiotropic effects; rad6 mutants are defective in postreplication repair, damage-induced mutagenesis, and sporulation (32, 45). The RAD6 protein has been purified in our laboratory; it is a ubiquitin-conjugating enzyme that can efficiently ubiquitinate histones in vitro $(25,60)$. Another gene, $R A D 18$, is required for postreplication repair but has no effect on UV mutagenesis or sporulation $(32,45)$. The RAD18 protein contains cysteine-rich zinc-binding motifs for DNA binding and also the putative nucleotide-binding domains (27). rad6 and rad18 mutants show about the same level of UV sensitivity and deficiency in postreplication repair, and the UV sensitivity of the rad6 rad18 double mutant is the same as that of either single mutant, indicating an epistatic relationship. Other genes in the $R A D 6$ epistasis group are $R E V 1$, $R E V 2$ (RAD5), and $R E V 3$. The $R E V 1$ and $R E V 3$ genes are essential for UV mutagenesis (32). The $R E V 3$-encoded protein shows homology to DNA polymerases (41), and it likely is a specialized DNA polymerase that primarily functions in the mutagenic bypass of lesions. Since the rev1 and rev3 mutations confer a low level of UV sensitivity and rev3 has no discernible effect on postreplication repair (45), mutagenic bypass constitutes a minor DNA repair pathway in yeast cells.

The role of $R A D 5(R E V 2)$ in mutagenic and nonmutagenic postreplication repair processes has been ambiguous. rad5 
TABLE 1, $S$, cerevisiae strains

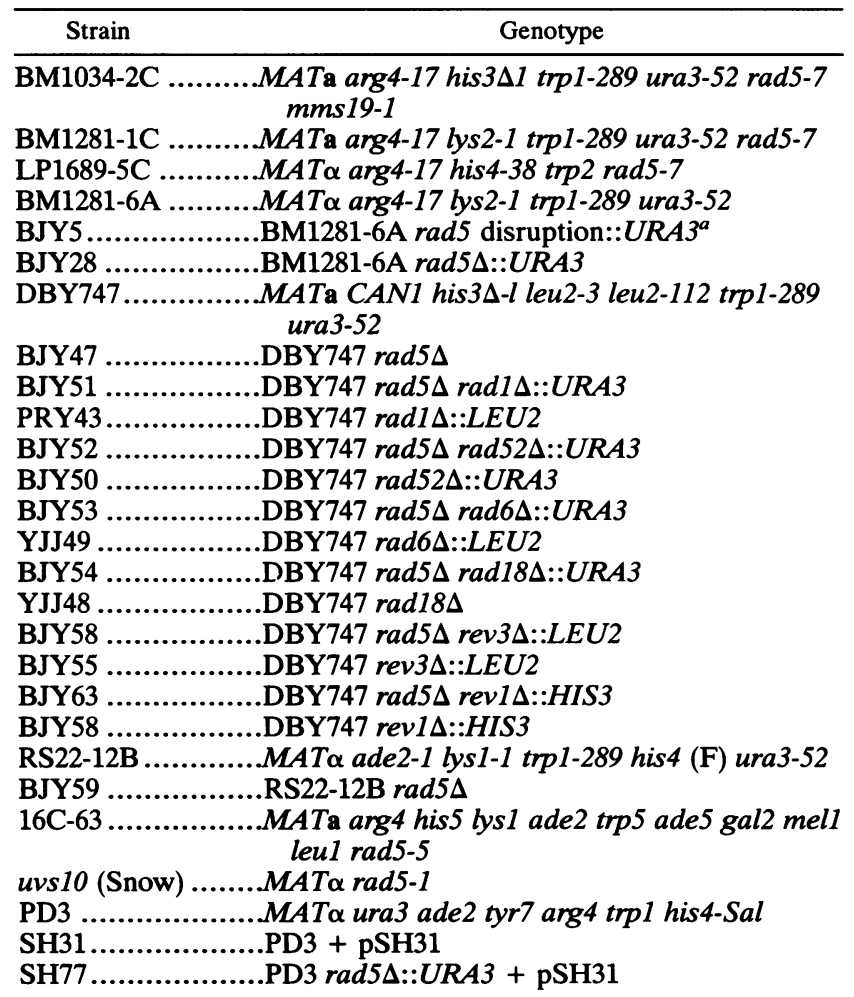

${ }^{a}$ The gene following the double colon indicates the selectable marker used in generating the $r a d \Delta$ mutation.

point mutations showed a lowering of UV mutagenesis of ochre alleles but had no effect on the reversion of amber, missense, or frameshift mutations (33). These results, however, could have arisen from leakiness of the rad5 mutant alleles examined. To define the role of $R A D 5$ in DNA repair and other cellular processes, we have cloned the $R A D 5$ gene and have studied the effect of the rad5 deletion (rad5 mutation on DNA repair, mutagenesis, and other cellular processes. We show that $R A D 5$ encodes a protein of $134 \mathrm{kDa}$ which contains all the seven domains that have been found associated with DNA helicases. A cysteine-rich motif present in RAD5 might coordinate the binding of zinc, promoting the binding of protein to DNA. Our genetic studies with the rad5 $\Delta$ mutation suggest that $R A D 5$ primarily functions with $R A D 18$ in an error-free postreplication repair pathway.

Eukaryotic genomes, including that of $S$. cerevisiae, contain regions where a single base or pair of bases is repeated many times. These repeated tracts consist of alternating GT, alternating GA, or poly(A) sequences (65). Because of their repetitive nature, these tracts undergo changes in size which could arise as a result of recombination or DNA polymerase slippage events. We show that $R A D 5$ affects the stability of genomic poly(GT) tracts.

\section{MATERIALS AND METHODS}

Strains and media. Yeast strains used in this study are listed in Table 1. Escherichia coli HB101, GM119, and DH5 $\alpha$ were used for propagation of plasmids; JM101 was used for propagation of M13 phage derivatives. YPD and synthetic complete media were prepared according to Sherman et al.
(55). Methyl methanesulfonate (MMS) was added to YPD medium at a concentration of $0.02 \%$. 5-Bromo-4-chloro-3indolyl- $\beta$-D-galactoside (X-Gal) plates were prepared as described by Rose and Botstein (50).

Transformations, DNA isolation, and other procedures. Nucleic acid purification, gel electrophoresis, and $E$. coli transformations were performed by standard protocols (40). Yeast cells were transformed by the lithium acetate method (24). Plasmids and phage constructions were carried out by using the low-melting-point agarose method (26).

Plasmids. Plasmids YEp24 (7) and YEplac195 (16) are high-copy-number plasmids that carry the yeast $2 \mu \mathrm{m}$ plasmid DNA origin of replication. YCplac33 and YIplac211 (16) are CEN4/ARS1 and integrating plasmids, respectively. All plasmids carry the $U R A 3$ gene as a yeast selectable marker. Plasmids used for studies of poly $(\mathrm{GT})$ tract instability were as follows.

(i) pSH31. Plasmid pSH31 was used to monitor stability of simple repetitive sequences (20). A 29-bp poly(GT) sequence was inserted into a BamHI site in the coding region of a lacZ gene that was fused to a $L E U 2$ promoter, creating an out-of-frame lacZ gene. Alterations in the tract length of poly $(\mathrm{GT})$ that restore the correct reading frame result in blue yeast colonies on medium containing X-Gal. The selective marker on the plasmid is TRP1.

(ii) pSH86. The 4.7-kb HindIII-PstI RAD5 DNA fragment was inserted into HindIII-PstI-digested pBluescriptIISK-.

(iii) pSH87. Plasmid pSH86 was digested with EcoRV, and the fragment containing the vector sequences and part of the $R A D 5$ insert was purified. The 1.2-kb URA3 BamHI DNA fragment was isolated from pM21 (54), treated with the Klenow fragment of DNA polymerase in order to generate blunt ends, and then ligated to the EcoRV fragment derived from pSH86.

Isolation of the $R A D 5$ gene. The yeast gene pool in YEp24 (8) was used to transform the rad5-7 mms19-1 yeast strain BM1034-2C to Ura ${ }^{+}$. The rad5-7 mutation is the same as the rev2-1 mutation (14). Over 8,000 transformants were replica plated onto synthetic complete medium lacking uracil and irradiated with UV radiation $\left(30 \mathrm{~J} / \mathrm{m}^{2}\right)(46)$. UV-resistant transformants were then grown under nonselective conditions to promote plasmid loss and subjected to screening for plasmid loss on 5-fluoro-orotic acid (6). Plasmid-dependent UV resistance was observed in four transformants. Plasmid DNA was isolated and used to transform the rad5-7 yeast strain BM1281-1C. Two plasmids that complemented the rad5-7 mutation carried overlapping inserts of 10.2 and 9.1 kb and were designated pBM102 and pBM125, respectively. Plasmid pBM102 was used in further studies.

DNA sequencing. DNA fragments of the $4.5-\mathrm{kb}$ yeast insert in pBM118 generated by digestion with restriction enzymes were subcloned into $\mathrm{M} 13 \mathrm{mp} 18$ and $\mathrm{M} 13 \mathrm{mp} 19$. Singlestranded M13 DNA containing RAD5 inserts was sequenced by the dideoxy-chain termination method (52) by using Sequenase version 2.0 (United States Biochemical Corp.) and M13 or RAD5 sequence-specific primers with deoxyadenosine $5^{\prime}-\left(\left[\alpha^{-35} S\right]\right.$ thio)triphosphate (5). In areas of strong secondary structure, dGTP was replaced by dITP in the sequencing reactions as described by the manufacturer. Both DNA strands were independently sequenced in the two laboratories.

Generation of a genomic rad5 $\Delta$ mutation. A rad5 $\Delta$ mutation was constructed by replacing an internal fragment of the $R A D 5$ open reading frame (ORF) with a $3.8-\mathrm{kb} B a m \mathrm{HI}$ fragment containing the $U R A 3$ gene flanked by two $1.1-\mathrm{kb}$ direct repeats of Salmonella hisG DNA (2). Plasmid pBJ22, 


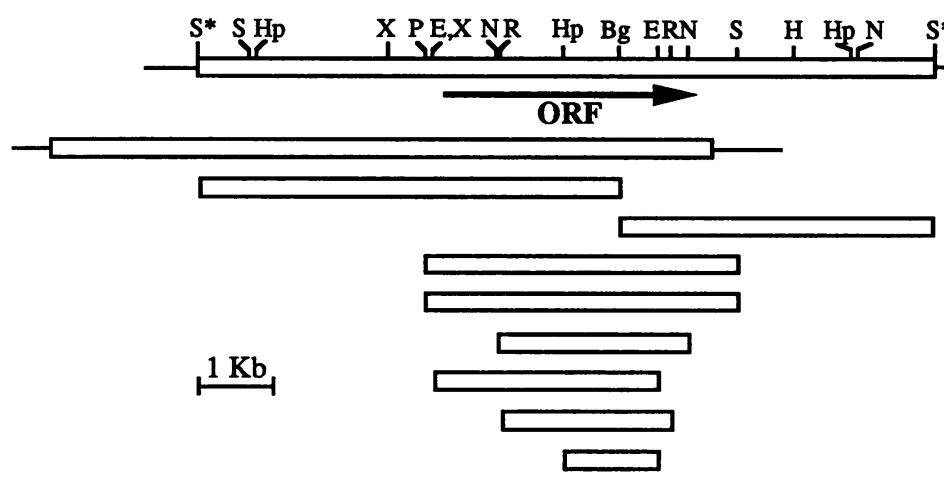

$\begin{array}{lcc}\text { Plasmid } & \text { Vector } & \begin{array}{c}\text { Complementation } \\ \text { of rad5-7 }\end{array} \\ \text { pBM102 } & 2 \mu & + \\ & & + \\ \text { pBM125 } & 2 \mu & + \\ \text { pBM116 } & 2 \mu & - \\ \text { pBM117 } & 2 \mu & - \\ \text { pBM118 } & 2 \mu & + \\ \text { pBJ6 } & \text { CEN/ARS } & + \\ \text { pBM151 } & 2 \mu & - \\ \text { pBM152 } & 2 \mu & - \\ \text { pBM154 } & 2 \mu & - \\ \text { pBJ4 } & \text { Integrating } & -\end{array}$

FIG. 1. Subcloning of the RAD5 gene. pBM102 and pBM125 contain 10.2- and 9.1-kb yeast inserts in YEp24. The ability ( + ) or inability $(-)$ of various subclones to complement the rad5-7 point mutation is shown. Restriction sites: S*, Sau3A-Bam HI; Bg, BglII; E, EcoRI; H, HindIII; Hp, HpaI; N, NcoI; P, PstI; R, EcoRV; S, SalI; X, XbaI.

when cut with $X b a \mathrm{I}$, generated a $5.5-\mathrm{kb}$ fragment that consists of 339 bp of DNA 5' to the RAD5 ORF, $673 \mathrm{bp}$ of N-terminal $R A D 5$ ORF, the 3.8-kb Salmonella hisG::yeast URA3::Salmonella hisG DNA, followed by 65 bp of C-terminal $R A D 5$ ORF plus 625 bp of DNA $3^{\prime}$ to the $R A D 5$ ORF, and the $\mathrm{XbaI}$ site of the pUC18 multicloning site. Transformation of yeast to $\mathrm{Ura}^{+}$with the $5.5-\mathrm{kb} \mathrm{XbaI}$ fragment resulted in a genomic deletion from +674 to +3443 of the $R A D 5$ gene. Strains which had become $\mathrm{Ura}^{-}$because of having lost the $U R A 3$ gene by recombination of the two Salmonella hisG sequences were selected for on 5-fluoroorotic acid. For studying the stability of poly(GT) tracts, we used a rad5 $\Delta$ strain in which a $2.3-\mathrm{kb} E c o \mathrm{RV}$ fragment of $R A D 5$ was replaced with URA3. This deletes sequences from +696 to +3078 in the $R A D 5$ ORF. The identity of the rad5 $\Delta$ mutations was verified by testing for allelism with rad5 point mutations and by Southern analyses.

UV survival, UV mutagenesis, and sporulation. Wild-type and mutant strains grown to mid-logarithmic phase $\left(2 \times 10^{7}\right.$ to $5 \times 10^{7}$ cells $/ \mathrm{ml}$ ) in YPD or selective medium were harvested, washed, and resuspended in sterile distilled water at $10^{8}$ cells per ml. For UV survival, cells were diluted, plated on selective or YPD medium, and irradiated (46). For UV-induced mutagenesis, cells were plated at $10^{7}$ cells per plate on the appropriate selective medium, UV irradiated, and grown for at least 5 days. Sporulation and dissection of asci were done as described elsewhere (55).

Measurement of poly(GT) tract instability. The measurement of tract instability was based on a method developed by Levinson and Gutman $(20,37)$. We used a plasmid (pSH31) with an out-of-frame insertion of poly(GT) within the coding sequence of $\beta$-galactosidase (20). Thus, an alteration of tract length that restored the reading frame could be detected by observing the frequency of blue yeast colonies on X-Gal plates (20). For this measurement, plasmid-containing cells were replica plated to plates lacking tryptophan (to ensure retention of the plasmid) and grown overnight at $32^{\circ} \mathrm{C}$. The cultures were then diluted to 100 cells per $\mathbf{m l}$ in liquid YPD; $100 \mu \mathrm{l}$ of this dilution was used to seed each of the wells of a 96-well microtiter dish, which was incubated at $32^{\circ} \mathrm{C}$ for 22 to $26 \mathrm{~h}$. The contents of each well were then transferred to a microcentrifuge tube and spun briefly to pellet the cells. The supernatant was removed, and the cells were resuspended in $1 \mathrm{ml}$ of sterile distilled water. The cells were then plated on $\mathrm{X}-\mathrm{Gal}$ medium lacking tryptophan, threonine, and leucine. Plates were incubated for 10 days to allow for complete development of the blue color. The proportion of cultures with no blue colonies was determined, and the rate of tract instability was calculated by the method of Luria and Delbruck (39) as modified by Lea and Coulson (34).

Nucleotide sequence accession number. The sequence obtained for the RAD5 gene has been deposited in GenBank under accession number M96644.

\section{RESULTS}

Cloning of the $\boldsymbol{R A D 5}$ gene. Since the rad5 point mutations confer a moderate level of sensitivity to UV irradiation (see Fig. 7), the RAD5 gene was cloned by complementation of the rad5-7 mutation in an excision repair-deficient background. The rad5-7 and mms19-1 mutations affect alternate DNA repair pathways; therefore, a yeast strain containing both the rad5-7 and mms 19-1 mutations is much more UV sensitive than a strain carrying either mutant allele alone. Complementation of either allele in the double mutant restores moderate UV resistance equivalent to that of the single mutant. Yeast strain BM1034-2C was transformed to $\mathrm{Ura}^{+}$with a yeast gene pool cloned into the multicopy vector YEp24. Two UV-resistant transformants were found to carry plasmids with overlapping $10.2-$ and $9.1-\mathrm{kb}$ inserts (Fig. 1) that fully complemented the rad5-7 mutation. Subcloning analyses indicated the rad5 complementing region to be contained within a 4.5-kb PstI-SalI fragment. This fragment complemented the rad5-7 mutation in both multicopy and low-copy-number plasmids pBM118 and pBJ6, respectively.

To establish that the 4.5-kb PstI-SalI fragment contained the $R A D 5$ gene and not an extragenic suppressor of the rad5-7 mutation, a genomic disruption of the cloned gene was generated in a $R A D^{+}$strain. An internal 1.15-kb HpaIEcoRI RAD5 fragment was cloned into the integrating plasmid YIplac211 (16), generating plasmid pBJ4. Digestion of this plasmid with $B g l I I$ generated free ends to direct homologous integration into the genome at the RAD5 locus. Transformants sensitive to both UV and MMS were crossed to the rad5-7 mutant strain, and the resulting diploids were found to be UV and MMS sensitive, confirming that the disrupted gene was allelic to rad5.

Sequence analysis of $R A D 5$. Both strands of the $4.5-\mathrm{kb}$ PstI-SalI complementing fragment were independently sequenced in the two laboratories, and a perfect match was found between the two sequences. RADS encodes a protein 


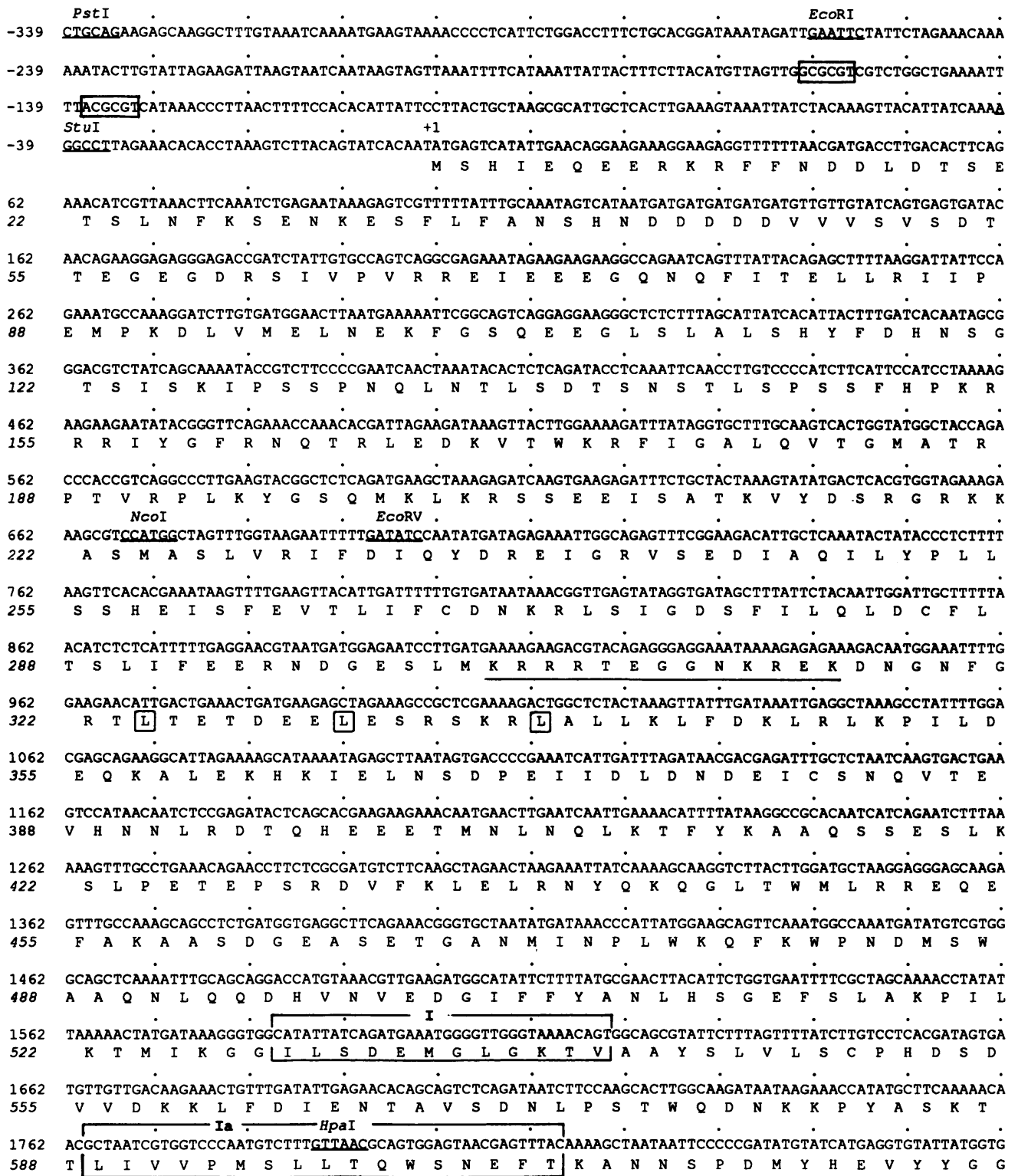

FIG. 2. Nucleotide sequence of $R A D 5$ and predicted amino acid sequence. Numbering of nucleotides is in relation to a $(+1)$ of the translation initiation codon, ATG. Dots mark every 10 bases. Some of the restriction sites are underlined. The MluI sequence at position -137 and a similar sequence at position -161 are boxed. Amino acids are numbered in italics, and the stop codon TAG is indicated by an asterisk. The seven helicase domains are boxed and indicated by roman numerals (I, Ia, and II to VI). Cysteine and histidine residues of the cysteine-rich zinc finger motif are circled. The basic region $\mathrm{N}$ terminal to the leucine zipper motif is underlined, and leucine residues of the heptad repeat motif are boxed.

of 1,169 amino acids with a calculated molecular mass of 134 $\mathrm{kDa}$. We have identified several interesting sequence motifs in the RAD5 protein which include the putative DNA helicase domains, a cysteine-rich portion, and a basic region followed by the leucine heptad repeat motif (Fig. 2).

RAD5 contains the seven conserved sequence motifs that have been identified in many proteins that bind and hydrolyze nucleotides and contain DNA or RNA helicase activities (17). Figure 3 shows a comparison of helicase domains I through VI among RAD5, RAD3 (49), and eIF-4A (42). The $S$. cerevisiae $R A D 3$ gene is required for excision repair of UV-damaged DNA and is essential for cell viability; the RAD3 protein is a single-stranded DNA-dependent ATPase, and it contains DNA and DNA - RNA helicase activities but has no RNA helicase activity $(4,58,59)$. eIF-4A encodes a eukaryotic translation initiation factor that exhibits an RNA helicase activity capable of unwinding mRNAs in an ATPdependent manner (48). In domain I, RAD5 contains the Walker type A sequence motif GXGKT (69) between residues 535 and 539. The conserved lysine $(\mathbf{K})$ in the GKT sequence has been proposed to interact with the $\alpha$ phosphoryl group of the bound nucleotide (13); its replacement with arginine in RAD3 abolishes the DNA and DNA - RNA helicase activities but not the ability to bind ATP $(4,57)$. Domain II contains the Walker type B box, which is characterized by the presence of three to five conservative 


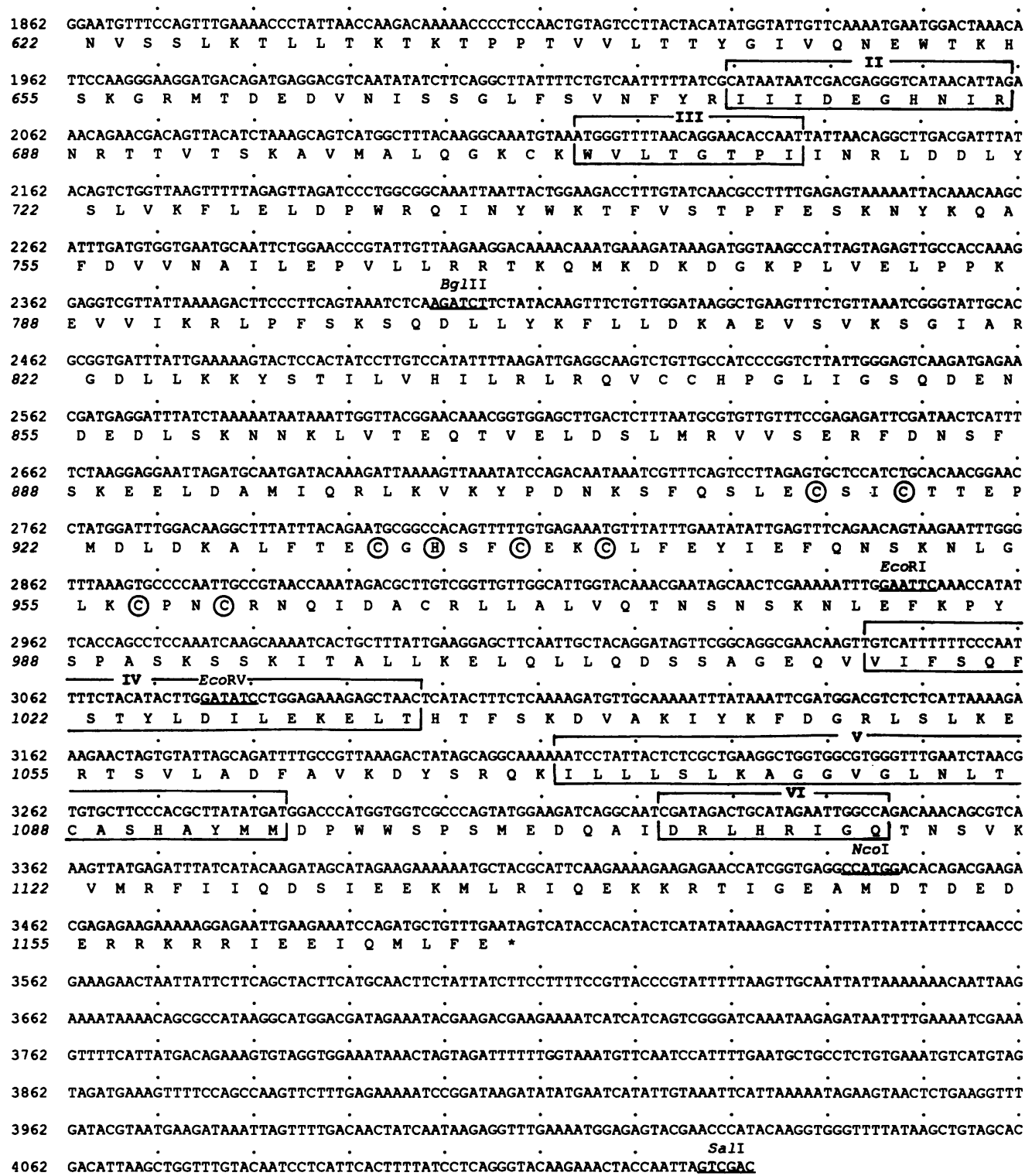

FIG. 2-Continued. hydrophobic residues followed by an aspartate residue. It has been proposed that aspartate interacts with $\mathrm{Mg}^{2+}$ on MgATP and that the hydrophobic residues of this sequence serve to exclude water from the ATP reaction center (13). The Walker type B box containing the hydrophobic residues followed by the highly conserved $\mathrm{DE}$ pair is located between residues 668 and 684 in RAD5. A special version of the Walker type B sequence, the DEAD box, is found in eIF-4A and other RNA helicases (38). In RAD5, the corresponding sequence is DEGH, and in RAD3, it is DEAH. In domain VI, RAD5 has the sequence HRIGQ, whereas the sequence HRIGR is invariant in eIF-4A and other RNA helicases (38). The absence of the DEAD box and HRIGR sequence motifs from RAD5 suggests that RAD5 might possess DNA helicase but not RNA helicase activity.

Near the carboxyl terminus, between residues 911 and 967, RAD5 contains a cysteine-rich motif (12) that resembles the sequence found in 11 other proteins (Fig. 4). This sequence has the consensus $\mathrm{CX}_{2} \mathrm{CX}_{11-30} \mathrm{CXHXF}(\mathrm{I}, \mathrm{L}) \mathrm{CX}_{2} \mathrm{CI}$ $(\mathrm{L}, \mathrm{M}) \mathrm{X}_{7-18} \mathrm{CPXC}$, in which the phenylalanine $(\mathrm{F})$, and isoleucine (I) residues are highly conserved but not invariant, and they can be replaced by other hydrophobic residues. This sequence differs from classical zinc finger motifs in the spacing between cysteine-cysteine/histidine pairs (usually 6 to 13 amino acids in zinc finger proteins), and the distance between the two finger domains is shorter than that found in other zinc finger proteins. The cysteine-rich domain identified in RAD5 and other proteins represents a novel motif which is possibly used for zinc binding and DNA binding. Some of these proteins function in DNA repair and recombination, while others encode transcriptional regulators. The yeast $R A D 18$ gene is required for postreplication repair of UV-damaged DNA, and our studies indicate that $R A D 5$ functions with $R A D 18$ in DNA repair (see below). RAG1 activates immunoglobulin gene arrangement and may encode a recombinase (53). Rpt-1 is a regulator of the interleu- 


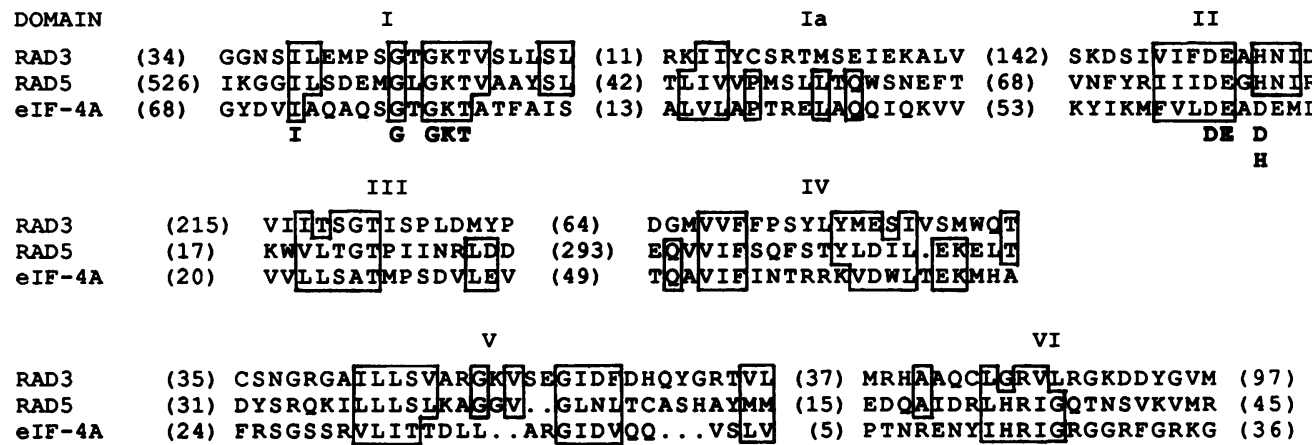

FIG. 3. Alignment of RAD5 with RAD3, a DNA helicase, and eIF-4A, an RNA helicase, in the seven conserved domains found in the superfamilies of DNA and RNA helicases. Identical and highly conserved residues shared between RAD5 and the two helicases are boxed. Residues shared among the three proteins in domains I and II are indicated in bold. The first and last set of numbers in parentheses indicate the distance from the amino terminus and carboxyl terminus, respectively, of each protein. Other numbers in parentheses indicate the number of amino acids separating domains.

kin-2 receptor gene (43), and Mel-18 and $\mathrm{Rfp}$ represent two potential oncoproteins $(61,62)$. The role of this motif in DNA binding is indicated from studies with Mel-18, in which a deletion mutation lacking the cysteine-rich domain has been shown to abolish Mel-18 DNA-binding activity (61). The lymphocytic choriomeningitis virus $\mathrm{Z}$ protein binds $\mathrm{Zn}^{2+}(51)$, suggesting that other members of this family might also bind $\mathrm{Zn}^{2+}$.

The $R A D 5$-encoded protein possesses the heptad repeat consensus sequence of a leucine zipper (30) that has been identified in several regulatory proteins. The leucine zipper region usually consists of four to five leucine residues in which leucines are separated from one another by six amino acids, and this region is immediately preceded by a segment rich in basic residues. RAD5 contains three leucines, each separated by six residues, and a basic sequence motif is present in front of this region. Alignment of this sequence in RAD5 with the leucine zipper domain in GCN4, a yeast transcriptional regulator (21), and c-Fos (68) and c-Jun oncoproteins (19) is shown in Fig. 5. In this region of 37 amino acids, RAD5 shares $38 \%$ identical and $62 \%$ conserved residues with GCN4. In GCN4, c-Fos, and c-Jun, the leucine repeat structure has been shown to be required for dimer formation, and the basic region represents the DNA-binding domain $(15,22,23,67)$. Helical wheel and helical net analyses (not shown) of RAD5 in the potential leucine zipper domain suggest the likelihood of helix formation, which can be stabilized by ion pairing. The leucine zipper domain in RAD5 could be involved in RAD5 forming a dimer with itself or complexing with another DNA repair protein, whereas the basic region might constitute a DNA-binding domain that differs from the cysteine-rich region in DNA recognition properties.

The rad5 $\Delta$ mutation causes slow growth. Since previous genetic studies used rad5 point mutations that could have been leaky, we generated a genomic deletion mutation of $R A D 5$ and examined its effect on viability, growth, sporulation, UV sensitivity, and UV mutagenesis.

The rad5 $\Delta$ mutant is viable, indicating that $R A D 5$ is not an essential gene; however, its growth rate is considerably slowed. The doubling time of the rad5 $\Delta$ mutant was $129 \pm 4$ min, in contrast to $90 \pm 8 \mathrm{~min}$ for the isogenic wild-type strain. The rad $18 \Delta$ and rad $6 \Delta$ mutations slow the growth rate even further than does the rad5 $\Delta$ mutation, to $165 \pm 13$ and $186 \pm 17 \mathrm{~min}$, respectively. We did not observe any effect of the rad5 $\Delta$ mutation on sporulation or spore viability.

$R A D 5$ functions with $R A D 18$ in DNA repair. Previous studies indicated that the rad5-7 mutation lowered the reversion frequency of ochre alleles but had no effect on reversion of other types of mutations. We found that UV-induced reversion of arg4-17, lys 1-1, lys 2-1, and ade2-1 ochre alleles is reduced but not abolished in the rad5 $\Delta$ mutant. The arg4-17 allele was affected the most. $\mathrm{Arg}^{+}$revertants in the rad5 $\Delta$ strain occurred at about a 10 -fold-lower rate than in the wild type; reversion of lys 1-1, lys 2-1, and ade2-1, however, was reduced only 2 - to 3 -fold (Table 2 ). The rad5 $\Delta$ mutation also did not affect the rate of UV-induced forward

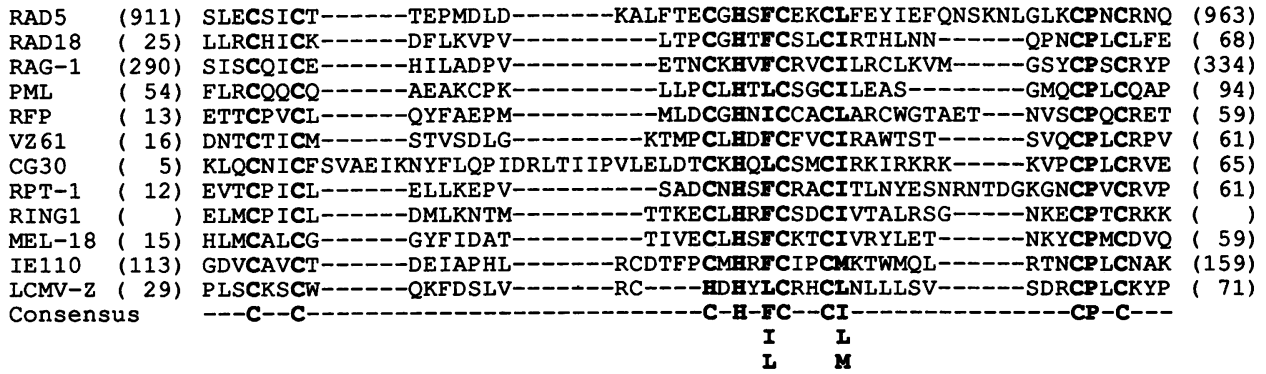

FIG. 4. Potential zinc-binding regions in RAD5 and other proteins. Conserved residues of the cysteine-rich consensus are shown in bold type. Numbers in parentheses indicate residue positions. References: RAD18 (27); RAG-1 (53); PML (28); Rfp (62); VZ61 (9); CG30 (66); Rpt-1 (43); RING1 (12); Mel-18 (61); IE110 (44); lymphocytic choriomeningitis virus (LCMV-Z) (51). 


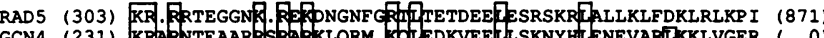

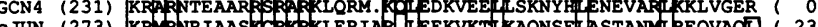

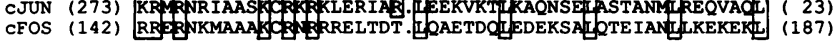

FIG. 5. Alignment of the potential leucine zipper domain of RAD5 with those of GCN4, c-Jun, and c-Fos. Basic residues and leucine residues of the heptad repeat motif shared among the proteins are boxed. Numbers in parentheses at the beginning and end indicate the distance from the amino terminus and carboxyl terminus, respectively, of each protein.

mutations at the $C A N 1^{\mathrm{s}}$ locus (Fig. 6). Thus, $R A D 5$ is not required for UV mutagenesis of most sites in the genome.

The $S$. cerevisiae UV repair genes have been classified into three epistasis groups. The $R A D 3$ group consists of genes involved in excision repair of UV-damaged DNA, the $R A D 6$ group genes function in postreplication repair and mutagenesis, and $R A D 52$ group genes are required for double-strand break repair and recombination. To determine the functional relationship of $R A D 5$ with other $R A D$ genes, we examined the UV sensitivity of the rad5 $\Delta$ mutation in combination with rad $\Delta$ mutations defective in excision repair, postreplication repair, or double-strand break repair (Fig. 7). Previously, Lemontt (36) examined the UV sensitivity of a rad5 point mutation in combinations with various rad and rev point mutations in nonisogenic genetic backgrounds. Our results differ from the results of those studies in several instances; however, because of the use of null mutations in an isogenic background, we consider our studies more reliable. The UV sensitivity of the rad5 $\Delta$ strain is identical to that of the rad5-7 strain (Fig. 7A). As expected, a synergistic increase in UV sensitivity is observed when a rad5 $\Delta$ mutation is combined with the rad1 $\Delta$ mutation defective in excision repair (Fig. 7A) or with the rad52 $\Delta$ mutation defective in double-strand break repair (Fig. 7C). An epistatic interaction is observed when the rad5 $\Delta$ mutation is combined with the rad $6 \Delta$ mutation defective in postreplication repair and UV mutagenesis (Fig. 7B). Even though the $R A D 18, R E V 1$, and $R E V 3$ genes belong in the $R A D 6$ epistasis group, they differ from each other in their effects on DNA repair and UV mutagenesis. The rad18 $\Delta$ mutant is as UV sensitive as the rad $6 \Delta$ mutation, but in contrast to rad6, the rad18 mutation has no effect on UV mutagenesis. The rev1 $\Delta$ and rev3 $\Delta$ mutations confer a low level of UV sensitivity, but the $R E V 1$ and $R E V 3$ genes are required for UV mutagenesis. We found an epistatic relationship between the rad5 $\Delta$ and rad18 $\Delta$ mutations, as indicated by the similar UV sensitivi-

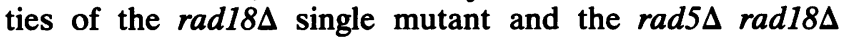
double mutant (Fig. 7D). In contrast, a synergistic increase

TABLE 2. Effect of the rad5 $\Delta$ mutation on UV-induced reversion of several ochre alleles ${ }^{a}$

\begin{tabular}{|c|c|c|c|c|c|c|c|c|}
\hline \multirow{3}{*}{$\begin{array}{l}\text { UV dose } \\
\left(\mathrm{J} / \mathrm{m}^{2}\right)\end{array}$} & \multicolumn{8}{|c|}{ 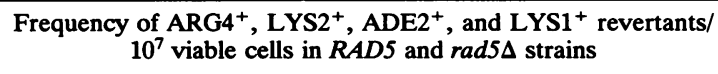 } \\
\hline & \multicolumn{2}{|c|}{ arg 4-17 } & \multicolumn{2}{|c|}{ lys2-1 } & \multicolumn{2}{|c|}{ ade2-1 } & \multicolumn{2}{|c|}{ lys 1-1 } \\
\hline & RAD5 & $\operatorname{rad} 5 \Delta$ & RADS & $\operatorname{rad} 5 \Delta$ & $R A D 5$ & $\operatorname{rad} 5 \Delta$ & RAD5 & $\operatorname{rad} 5 \Delta$ \\
\hline 5.0 & 14.1 & 2.2 & 14.7 & 6.6 & 6.3 & 3.0 & 12.5 & 7.5 \\
\hline 7.5 & 36.2 & 4.4 & 32.9 & 15. & 15.7 & 4.4 & 24.2 & 13.1 \\
\hline 10.0 & 62.6 & 6.1 & 67.2 & 21.6 & 26.5 & 10.6 & 43.1 & 16.7 \\
\hline
\end{tabular}

a The isogenic strains BM1281-6A $\left(R A D^{+}\right)$and BJY28 (rad5 $)$were used to test reversion of the arg 4-17 and hys2-1 alleles, and the isogenic strains RS22-12B $\left(R A D^{+}\right)$and BJY59 $(\mathrm{rad} 5 \Delta)$ were used to test reversion of the ade $2-1$ and $h y s 1-1$ alleles. Spontaneous revertants arising in unirradiated cells were subtracted from the data.

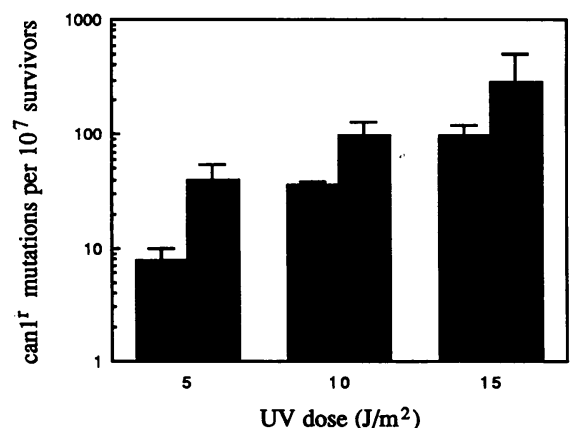

FIG. 6. Evidence that the UV-induced $C A N 1^{\mathrm{s}}$-to-can $1^{\mathrm{r}}$ mutation rate is not affected by the rad5 $\Delta$ mutation. Survival and mutation rate after UV irradiation were determined by using mid-logarithmic cells of the isogenic strains DBY747 $\left(R A D^{+}\right.$; shaded bars) and BJY47 (rad5 $\Delta$; black bars). Cells were plated on synthetic complete medium to determine survival and on synthetic complete medium lacking arginine but supplemented with canavanine to determine the frequency of can $^{\mathrm{r}}$ mutants. Plates were irradiated with UV light and incubated at $30^{\circ} \mathrm{C}$ in the dark. The data were obtained from at least two independent experiments. The standard deviation is indicated above each bar.

in UV sensitivity was observed when the rad5 $\Delta$ mutation was combined with either the rev1 $\Delta$ mutation (Fig. 7E) or the rev3 $\Delta$ mutation (Fig. $7 \mathrm{~F}$ ). These observations suggest that $R A D 5$ functions with $R A D 18$ in an error-free postreplication repair pathway.

$R A D 5$ is required for the wild-type rate of instability of poly(GT) sequences. Tracts of simple repeat sequence DNA have been found in every eukaryote examined. One particularly common class of these repeats is poly(GT) tracts [polyd(GT/CA)]. These tracts range in size from 20 to $60 \mathrm{bp}$ and are common in eukaryotic genomes. For example, the human genome has about $10^{5}$ copies, while the yeast genome contains about 50 to 100 copies $(18,70)$. Although a number of roles have been proposed for these sequences, their function in the genome, if any, is not known. One interesting feature of the tracts is their extreme polymorphic nature at allelic locations $(29,71)$. This feature has attracted much interest in simple sequences as DNA fingerprinting and mapping tools (64).

In a previous study (20), we found that 29-bp poly(GT) tracts were unstable in $S$. cerevisiae, changing in length at a rate of about $1.4 \times 10^{-4}$ per mitotic division. This instability was monitored by using a plasmid in which an out-of-frame poly(GT) tract was inserted into the coding sequence of $E$. coli $\beta$-galactosidase; yeast cells containing this plasmid form white colonies on X-Gal plates. Deletions and additions of sequences within the tract that resulted in an in-frame insertion could be detected by the frequency of blue yeast colonies on X-Gal plates.

To assay the role of $R A D 5$ on the stability of $\operatorname{poly}(\mathrm{GT})$ tracts, we used the RAD5 strain SH31, which is strain PD3 carrying plasmid pSH31 (20), and the rad5 $\Delta$ strain SH77, which is isogenic with SH31. We decided to examine the effects of the rad5 $\Delta$ mutation on tract stability because we had previously identified a spontaneous mutation of rad5 that appeared to stimulate frameshifting; however, since this stimulation required at least one additional mutation in an unidentified locus, we investigated the effect of the rad5 null mutation on frameshifting in an otherwise wild-type genetic background. Since plasmid pSH31 in strains SH31 and SH77 contains an out-of-frame insertion of $\operatorname{poly}(\mathrm{GT})$ in the $\beta$-ga- 

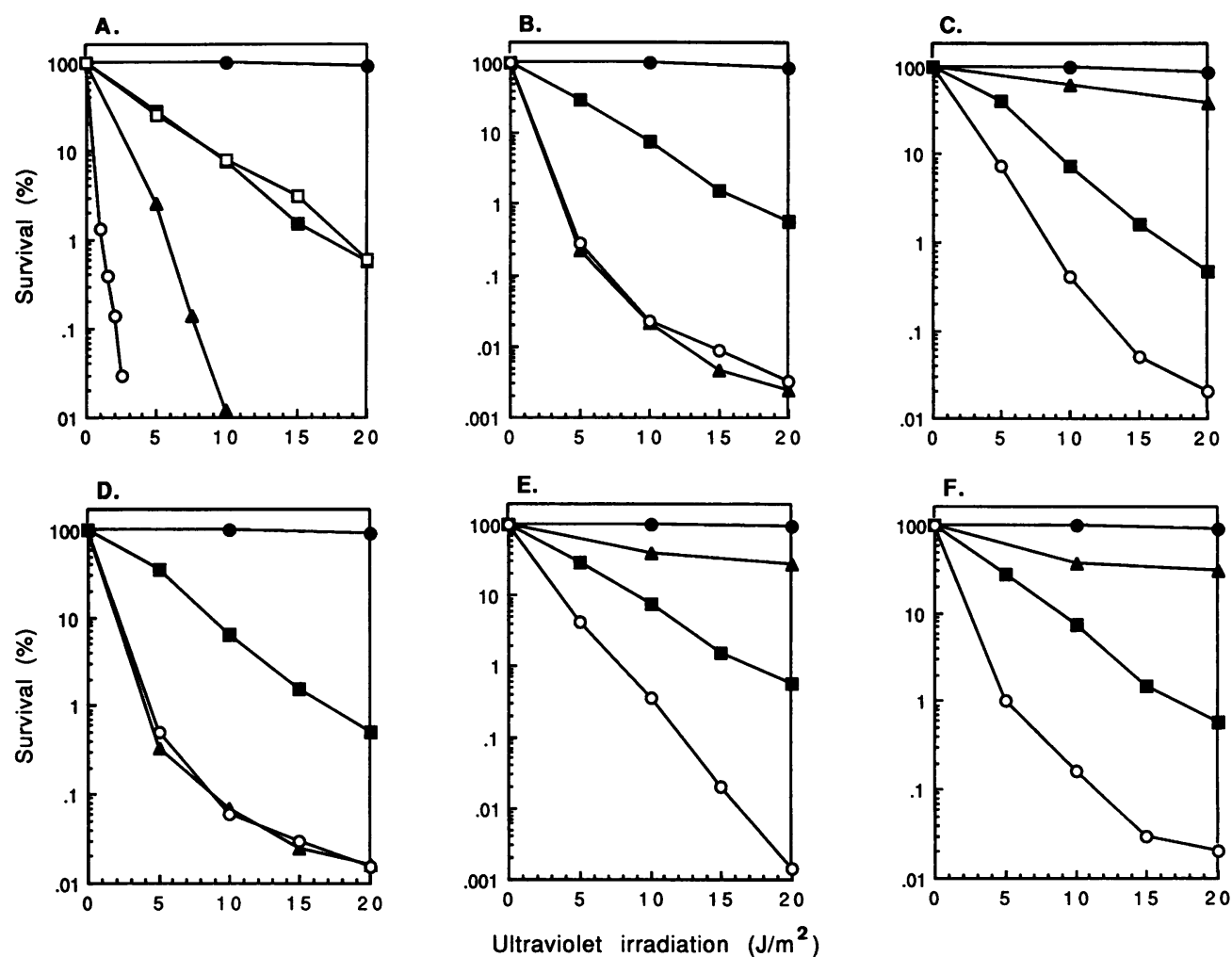

FIG. 7. UV survival of different rad5 mutants. The rad5 $\Delta$ mutation was generated in combination with various other rad or rev deletion mutations in yeast strain DBY747 to determine epistasis. Symbols: $\bullet, R A D^{+} ; \boldsymbol{\omega}, \operatorname{rad} 5 \Delta ; \Delta, \operatorname{rad} 1 \Delta(\mathrm{A}), \operatorname{rad} 6 \Delta(\mathrm{B}), \operatorname{rad52} \Delta(\mathrm{C}), \operatorname{rad18\Delta }(\mathrm{D})$, $\operatorname{rev} 1 \Delta(\mathrm{E})$, and $\operatorname{rev} 3 \Delta(\mathrm{F}) ; \mathrm{O}, \operatorname{rad} 1 \Delta \operatorname{rad} 5 \Delta(\mathrm{A}), \operatorname{rad} 6 \Delta \operatorname{rad} 5 \Delta(\mathrm{B}), \operatorname{rad} 52 \Delta \operatorname{rad} 5 \Delta(\mathrm{C}), \operatorname{rad} 18 \Delta \operatorname{rad} 5 \Delta(\mathrm{D}), \operatorname{rev} 1 \Delta \operatorname{rad} 5 \Delta(\mathrm{E})$, and $\operatorname{rev} 3 \Delta \operatorname{rad} 5 \Delta(\mathrm{F}) ;$ $\square(\mathrm{A})$, the rad5-7 mutation in yeast strain LP1689-5C.

lactosidase gene, yeast cells containing the plasmid are white on X-Gal plates unless the poly(GT) tract undergoes an alteration in size to restore the reading frame. Thus, the frequency of blue colonies on X-Gal reflects the frequency of changes in tract length. The number of independent cultures without blue colonies was used to calculate the rate by the Luria-Delbruck fluctuation method (39) as modified by Lea and Coulson (34). The rad5 $\Delta$ mutation lowered the rate of instability of poly(GT) sequences 10 -fold compared with the rate observed in the wild-type strain (Table 3). DNA sequence analysis indicated that in 17 of 17 plasmids derived from blue colonies, the length of the poly $(\mathrm{GT})$ tract was altered. The types of alterations were similar to those observed in $R A D 5$ strains (20). In the 17 plasmids sequenced, the observed changes were -2 deletions (nine plasmids), +2 insertions (six plasmids), one +4 insertion, and one -14 deletion. As observed previously (20), +2 insertions, although they do not restore the correct reading frame, result in production of $\beta$-galactosidase activity as a consequence of translational frameshifting.

\section{DISCUSSION}

$R A D 5$ encodes a protein of $134 \mathrm{kDa}$ which contains the various domains found in proteins that bind and hydrolyze nucleotides. A comparison of these domains with those

TABLE 3. Effect of $R A D 5$ on rates of frameshifts of simple repetitive DNA sequences inserted upstream of the $\beta$-galactosidase gene

\begin{tabular}{|c|c|c|c|c|c|c|}
\hline Strain & $\begin{array}{c}R A D 5 \\
\text { genotype }\end{array}$ & $\begin{array}{c}\text { Tract } \\
\text { (nontranscribed } \\
\text { strand) }\end{array}$ & $\begin{array}{l}\text { No. of } \\
\text { cultures }\end{array}$ & $\begin{array}{l}\text { Avg no. of } \\
\text { cells/culture }\end{array}$ & $\begin{array}{l}\text { No. of cultures with } \\
\text { no detectable } \\
\text { frameshifts }\end{array}$ & $\begin{array}{l}\text { Rate }\left(10^{-4}\right) \\
\quad \pm \mathrm{SE}^{b}\end{array}$ \\
\hline $\mathrm{SH} 31^{c}$ & $R A D 5$ & $(\mathrm{GT})_{14} \mathrm{G}$ & $\begin{array}{l}29 \\
47 \\
20\end{array}$ & $\begin{array}{r}1,027 \\
969 \\
2,210\end{array}$ & $\begin{array}{l}26 \\
43 \\
15\end{array}$ & $\begin{array}{c}1.9 \pm 0.6 \\
1.0 \pm 0.4 \\
1.3 \pm 0.6 \\
(1.4)\end{array}$ \\
\hline SH77 & $\operatorname{rad} 5 \Delta:: U R A 3$ & $(\mathrm{GT})_{14} \mathrm{G}$ & $\begin{array}{l}16 \\
17\end{array}$ & $\begin{array}{l}6,430 \\
6,202\end{array}$ & $\begin{array}{l}14 \\
16\end{array}$ & $\begin{array}{l}0.2 \pm 0.1 \\
0.1 \pm 0.1 \\
(0.15)\end{array}$ \\
\hline
\end{tabular}

a Since all tracts were out-of-frame insertions in the $\beta$-galactosidase gene, frameshifts were detected by cells that formed blue colonies on $\mathrm{X}$-Gal plates.

${ }^{b}$ Calculated by the Luria-Delbruck (39) method as modified by Lea and Coulson (34). Averages are given in parentheses.

$c$ Data from a previous study (20). 


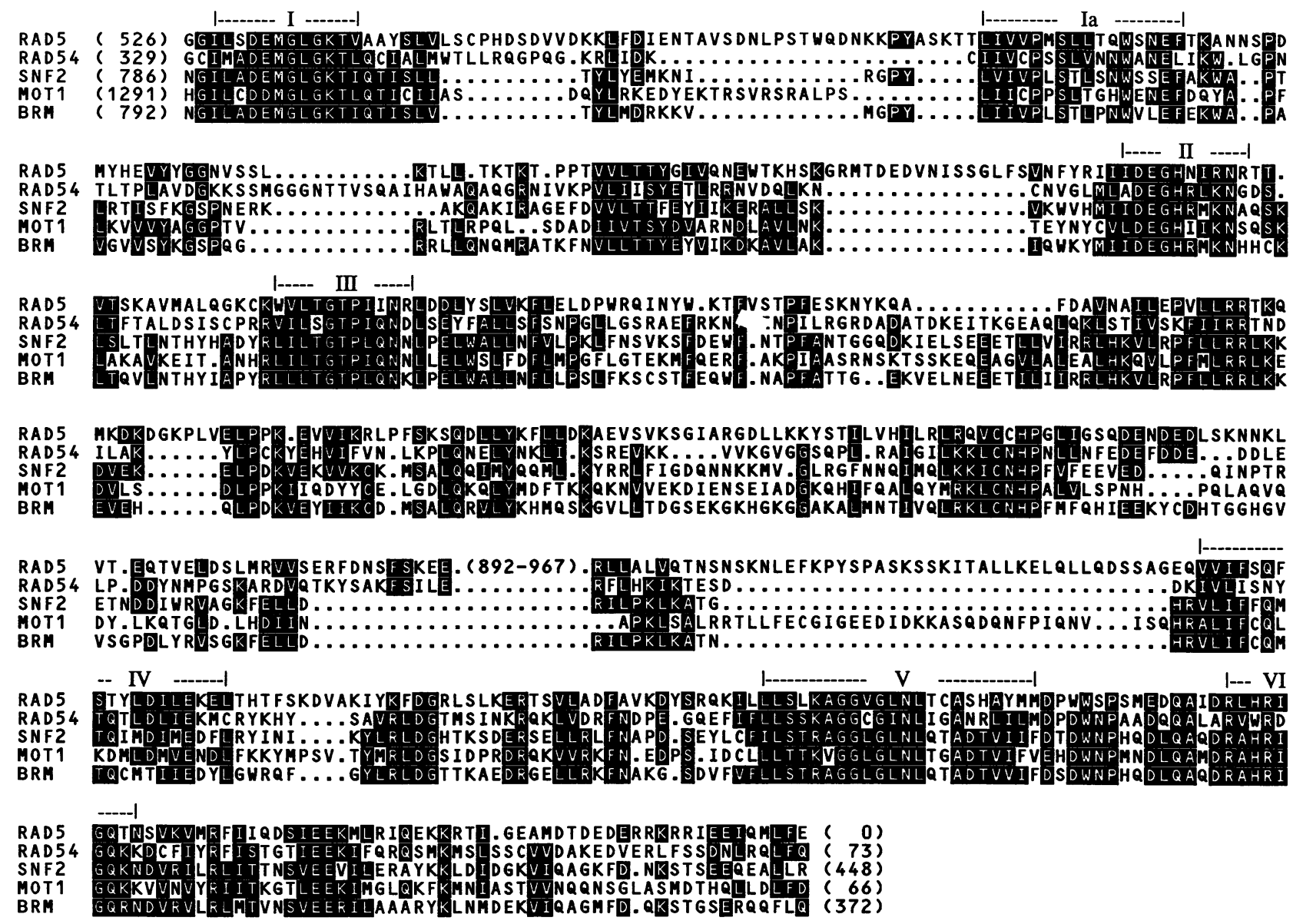

FIG. 8. Alignment of RAD5 with other potential DNA helicases in the new subfamily of yeast and Drosophila proteins. Positions that have three of five matching or homologous residues $(I=L=V, S=T, D=E$, and $R=K)$ are depicted by white-on-black lettering. The seven helicase domains are indicated by roman numerals (I, Ia, and II to VI). Amino acids from positions 892 to 967 of RAD5 are not shown because there is no homology with the other proteins in this region. This region contains the potential zinc-binding domain of RAD5. Numbers in parentheses at the beginning and end of each protein sequence indicate the distance from the amino terminus and carboxyl terminus, respectively.

present in the yeast RAD3 protein, a DNA helicase, and mammalian eIF-4A, an RNA helicase, suggests that RAD5 might possess a DNA helicase activity. We have observed that RAD5 is a member of a subfamily of proteins that are dramatically conserved over most of the residues in the seven conserved domains present in helicases (Fig. 8). This family includes the yeast protein RAD54, involved in DNA double-strand break repair and recombination (11), the yeast SNF2 protein, involved in transcriptional activation of glucose-repressible and other genes (31), MOT1, encoded by an essential yeast gene affecting the expression of pheromoneresponsive genes (10), and the Drosophila transcriptional activator Brm (63). In addition to the helicase domains, RAD5 contains a cysteine-rich zinc-binding motif and a basic region followed by the leucine zipper motif, sequences which might endow RAD5 with different DNA-binding capabilities.

In a recent study (1), the cloning of $R E V 2$ (RAD5) was reported; however, no evidence that the cloned gene was $R A D 5$ was presented. The reported restriction map is not in any obvious way related to the map derived in our study. We have several arguments indicating that the gene that we have isolated is $R A D 5$ : (i) our two groups cloned the same gene complementing the rad5 mutation independently, (ii) the cloned gene maps to chromosome XII (the location of $R A D 5$ ), and (iii) mutations made in vitro in the cloned gene in our two groups and transplaced into the genome fail to complement rad5 mutations.

Our genetic studies with the rad5s mutation confirm previous observations with the rad5 point mutants that $R A D 5$ is not required for UV mutagenesis. The rad5 $\Delta$ mutation had no effect on the frequency of UV-induced forward mutations from $C A N 1^{\text {s }}$ to $c a n 1^{\mathrm{r}}$. As has been shown previously for the rad5-7 (rev2-1) point mutation (35), the rad5 $\Delta$ mutation lowered the frequency of UV-induced reversion of ochre alleles a few fold. The UV sensitivity of double-mutant combinations of the rad5 $\Delta$ mutation with the rads mutations belonging to different epistasis groups clearly puts $R A D 5$ in the $R A D 6$ epistasis group. Our findings of epistatic interaction between the rad5 $\Delta$ and rad18 $\Delta \mathrm{mu}$ tations and of a synergistic increase in UV sensitivity in combinations of the rad5 $\Delta$ mutation with the rev1 $\Delta$ or the rev3 $\Delta$ mutation suggest that $R A D 5$ functions with $R A D 18$ in the error-free postreplication repair pathway. The lower

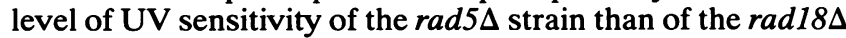
strain could mean that RAD5 acts by increasing the effi- 
ciency of RAD18 function. Whether RAD5 affects UV mutagenesis of ochre alleles by direct participation in mutagenic bypass of certain damaged sites, or whether it reflects an indirect pleiotropic effect, remains to be determined.

The putative ATPase/DNA helicase and DNA-binding activities in RAD5 could function in conjunction with RAD18 in translesion DNA synthesis. RAD18 contains the cysteine-rich zinc-binding domain which is similar to that found in RAD5 (Fig. 4), and RAD18 contains the nucleotidebinding domain but not the additional domains found in DNA helicases. In translesion DNA synthesis, RAD5 could assist RAD18 in the branch migration reaction, or it could affect the polymerization step either by increasing the processivity of DNA polymerase or by unwinding the duplex DNA.

Our studies indicate that the $R A D 5$ gene product has a role in altering the length of simple repetitive tracts. These alterations could arise as a result of recombination (for example, unequal sister strand recombination) or DNA polymerase slippage. Since the events occur at a high frequency relative to most types of mitotic recombination and are unaffected by mutations in RAD52 (20), a gene required for recombination, we favor the explanation that the frameshift events reflect DNA polymerase slippage. In this mechanism, during DNA replication, there is a transient dissociation of the template and primer strands (56). When the strands reassociate, they associate out of register. Continued DNA synthesis results either in a deletion (if there is an unpaired loop in the template strand) or an insertion (if there is an unpaired loop in the primer strand). RAD5mediated dissociation of the template and primer strands during replication might account for the increased incidence of DNA polymerase slippage events.

The genes required for DNA synthesis in $S$. cerevisiae are coordinately expressed at the $G_{1} / S$ phase boundary, and upstream sequences of these regulated genes contain at least one copy of the MluI sequence $5^{\prime}$-ACGCGT-3', which has been shown to activate transcription in a cell cycle-dependent manner (3). The upstream region of $R A D 5$ contains one MluI sequence at position -137 and another related sequence, 5'-GCGCGT-3', at position -161 that differs from the MluI sequence by a single base change (Fig. 2). The presence of the MluI sequence is highly suggestive that transcription of $R A D 5$ is cell cycle dependent, and this raises the possibility that RAD5 might be a component of the DNA replication machinery.

\section{ACKNOWLEDGMENTS}

We are grateful to Frank Larimer and Chris Lawrence for providing plasmid $\mathrm{pFL} 240$ and plasmid $\mathrm{pRV} 3 \Delta \mathrm{L}$ used for generating a yeast genomic rev1 deletion and a rev3 deletion, respectively. We thank Jeremy Thorner, Marion Carlson, David Schild, and Mark Goebl for sending us relevant unpublished sequence information prior to publication, and we thank John Game for yeast strains.

This work was supported by Public Health Service grant GM19261 from the National Institutes of Health and by ACS grant NP-712.

\section{REFERENCES}

1. Ahne, F., S. Wendel, and F. Eckardt-Schupp. 1990. Molecular analysis of the REV 2 gene of Saccharomyces cerevisiae-a review. Radiat. Environ. Biophys. 29:293-301.

2. Alani, E., L. Cao, and N. Kleckner. 1987. A method for gene disruption that allows repeated use of URA3 selection in the construction of multiply disrupted genes. Genetics 116:541-545.
3. Andrews, B. J. 1992. Dialogue with the cell cycle. Nature (London) 355:393-394.

4. Bailly, V., P. Sung, L. Prakash, and S. Prakash. 1991. DNARNA helicase activity of RAD3 protein of Saccharomyces cerevisiae. Proc. Natl. Acad. Sci. USA 88:9712-9716.

5. Biggin, M. D., T. J. Gibson, and G. F. Hong. 1983. Buffer gradient gels and ${ }^{35} \mathrm{~S}$ label as an aid to rapid DNA sequence determination. J. Biol. Chem. 134:315-319.

6. Boeke, J. D., F. LaCroute, and G. R. Fink. 1984. A positive selection for mutants lacking orotidine-5'-phosphate decarboxylase activity in yeast: 5-fluoro-orotic acid resistance. Mol. Gen. Genet. 197:345-346.

7. Botstein, D., S. Falco, S. Stewart, M. Brennan, S. Scherer, D. Stinchcomb, K. Struhl, and R. Davis. 1979. Sterile host yeast (SHY), a eukaryotic system of biological containment for recombinant DNA experiments. Gene 8:17-24.

8. Carlson, M., and D. Botstein. 1982. Two differentially regulated mRNA's with different 5 ' ends encode secreted and intracellular forms of yeast invertase. Cell 28:145-154.

9. Davidson, A. J., and J. E. Scott. 1986. The complete DNA sequence of varicella-zoster virus. J. Gen. Virol. 67:1759-1816.

10. Davis, J. L., R. Kunisawa, and J. Thorner. 1991. A presumptive helicase (MOT1 gene product) affects gene expression and is required for viability in the yeast Saccharomyces cerevisiae. Mol. Cell. Biol. 12:1879-1892.

11. Emery, H. S., D. Schild, D. E. Kellogg, and R. K. Mortimer. 1991. Sequence of RAD5:, a Saccharomyces cerevisiae gene involved in recombination and repair. Gene 104:103-106.

12. Freemont, P. S., I. M. Hanson, and J. Trowsdale. 1990. A novel cysteine-rich sequence motif. Cell 64:483-484.

13. Fry, D. C., S. A. Kuby, and A. S. Mildvan. 1986. ATP-binding of adenylate kinase: mechanistic implications of its homology with ras-encoded $\mathrm{p} 21, \mathrm{~F}_{1}-\mathrm{ATPase}$, and other nucleotide-binding proteins. Proc. Natl. Acad. Sci. USA 83:907-911.

14. Game, J. C., and B. S. Cox. 1971. Allelism tests of mutants affecting sensitivity to radiation in yeast and a proposed nomenclature. Mutat. Res. 12:328-331.

15. Gentz, R., F. J. Rauscher III, C. Abate, and T. Curran. 1989. Parallel association of Fos and Jun leucine zippers juxtaposes DNA binding domains. Science 243:1695-1699.

16. Gietz, R. D., and A. Sugino. 1988. New yeast-Escherichia coli shuttle vectors constructed with in vitro mutagenized yeast genes lacking six-base pair restriction sites. Gene 74:527-534.

17. Gorbalenya, A. E., E. V. Koonin, A. P. Doncheko, and V. L. Blinov. 1989. Two related superfamilies of putative helicases involved in replication, recombination, repair and expression of DNA and RNA genomes. Nucleic Acids Res. 17:4713-4730.

18. Hamada, H., M. G. Petrino, and T. Kakunaga. 1982. A novel repeated element with Z-DNA forming potential is widely found in evolutionarily diverse eukaryotic genomes. Proc. Natl. Acad. Sci. USA 79:6465-6469.

19. Hattori, K., P. Angel, M. M. Le Beau, and M. Karin. 1988. Structure and chromosomal localization of the functional intronless human JUN protooncogene. Proc. Natl. Acad. Sci. USA 85:9148-9152.

20. Henderson, S. T., and T. D. Petes. 1992. Instability of simple sequence DNA in Saccharomyces cerevisiae. Mol. Cell. Biol. 12:2749-2757.

21. Hinnebusch, A. G. 1984. Evidence for translational regulation of the activator of general amino acid control in yeast. Proc. Natl. Acad. Sci. USA 81:6442-6446.

22. Hope, I. A., and K. Struhl. 1986. Functional dissection of a eukaryotic transcriptional activator protein, GCN4 of yeast. Cell 46:885-894.

23. Hope, I. A., and K. Struhl. 1987. GCN4, a eukaryotic transcriptional activator protein, binds as a dimer to target DNA. EMBO J. 6:2781-2784.

24. Ito, H., Y. Fukuda, K. Murata, and A. Kimura. 1983. Transformation of intact yeast cells treated with alkali cations. J. Bacteriol. 153:163-168.

25. Jentsch, S., J. P. McGrath, and A. Varshavsky. 1987. The yeast DNA repair gene $R A D 6$ encodes a ubiquitin-conjugating enzyme. Nature (London) 329:131-134. 
26. Johansen, T. 1988. Cloning of specific restriction fragments directly from low-melting point agarose gels. DNA Protein Eng. Tech. 1:57-59.

27. Jones, J. S., S. Weber, and L. Prakash. 1988. The Saccharomyces cerevisiae $R A D 18$ gene encodes a protein that contains potential zinc finger domains for nucleic acid binding and a putative nucleotide binding sequence. Nucleic Acids Res. 16: 7119-7131.

28. Kakizuka, A., W. H. Miller, Jr., K. Umesono, R. P. Warrell, Jr., S. R. Frankel, V. V. V. S. Murty, E. Dmitrovski, and R. M. Evans. 1991. Chromosomal translocation $t(15 ; 17)$ in human acute promyelocytic leukemia fuses RAR $\alpha$ with a novel putative transcription factor, PML. Cell 66:663-674.

29. Kashi, Y., Y. Tikochinsky, E. Genislav, F. Iraqi, A. Nave, J. S. Beckman, Y. Gruenbaum, and M. Soller. 1990. Large restriction fragments containing poly-TG are highly polymorphic in a variety of vertebrates. Nucleic Acids Res. 18:1129-1132.

30. Landshultz, W. H., P. F. Johnson, and S. L. McKnight. 1988. The leucine zipper: a hypothetical structure common to a new class of DNA binding proteins. Science 240:1759-1764.

31. Laurent, B. C., X. Yang, and M. Carison. 1992. An essential Saccharomyces cerevisiae gene homologous to $S N F 2$ encodes a helicase-related protein in a new family. Mol. Cell. Biol. 12: 1893-1902.

32. Lawrence, C. W. 1982. Mutagenesis in Saccharomyces cerevisiae. Adv. Genet. 21:173-254.

33. Lawrence, C. W., and R. B. Christensen. 1978. Ultravioletinduced reversion of $c y c 1$ alleles in radiation sensitive strains of yeast. II. rev2 mutant strains. Genetics 90:213-226.

34. Lea, D. E., and C. A. Coulson. 1949. The distribution of the number of mutants in bacterial populations. J. Genet. 49:264 285.

35. Lemontt, J. F. 1970. Mutants of yeast defective in mutation induced by ultraviolet light. Genetics 68:21-33

36. Lemontt, J. F. 1971. Pathways of ultraviolet mutability in Saccharomyces cerevisiae. I. Some properties of double mutants involving uvs9 and rev. Mutat. Res. 13:311-317.

37. Levinson, G., and G. A. Gutman. 1987. High frequency of short frameshifts in poly-CA/GT tandem repeats borne by bacteriophage M13 in Escherichia coli K-12. Nucleic Acids Res. 15: 5323-5338.

38. Linder, P., P. F. Lasko, M. Ashburner, P. Leroy, P. J. Nielson, K. Nishi, J. Schnier, and P. P. Slonimski. 1989. Birth of the D-E-A-D box. Nature (London) 337:121-122.

39. Luria, S. E., and M. Delbruck. 1943. Mutations of bacteria from virus sensitivity to virus resistance. Genetics 28:491-511.

40. Maniatis, T., E. F. Fritsch, and J. Sambrook. 1982. Molecular cloning: a laboratory manual. Cold Spring Harbor Laboratory, Cold Spring Harbor, N.Y.

41. Morrison, A., R. B. Christensen, J. Alley, A. K. Beck, E. G. Bernstine, J. F. Lemontt, and C. W. Lawrence. 1989. REV3, a Saccharomyces cerevisiae gene whose function is required for induced mutagenesis, is predicted to encode a nonessential DNA polymerase. J. Bacteriol. 171:5659-5667.

42. Neilson, P. J., G. K. McMaster, and H. Trachel. 1985. Cloning of eukaryotic protein synthesis initiation factor genes: isolation and characterization of cDNA clones encoding factor eIF-4A. Nucleic Acids Res. 13:6867-6880.

43. Patarca, R., J. Schwartz, R. P. Singh, Q. T. Kong, E. Murphy, Y. Anderson, F. Y. W. Sheng, P. Singh, K. A. Johnson, S. M. Guarnagia, T. Durfee, F. Blattner, and H. Cantor. 1988. rpt-1, an intracellular protein from helper/inducer $T$ cells that regulates gene expression of interleukin 2 receptor and human immunodeficiency virus type 1 . Proc. Natl. Acad. Sci. USA 85:2733-2737.

44. Perry, L. J., F. J. Rixon, R. D. Everett, M. C. Frame, and D. J. McGeoch. 1986. Characterization of the IE110 gene of herpes simplex virus type 1 . J. Gen. Virol. 67:2365-2380.

45. Prakash, L. 1981. Characterization of postreplication repair in the yeast Saccharomyces cerevisiae and effects of the rad6, rad18, rev3 and rad52 mutations. Mol. Gen. Genet. 184:471478

46. Prakash, L., and S. Prakash. 1977. Isolation and characteriza- tion of MMS-sensitive mutants of Saccharomyces cerevisiae. Genetics 86:33-55.

47. Prakash, S., P. Sung, and L. Prakash. 1990. Structure and function of DNA repair genes of Saccharomyces cerevisiae, $\mathrm{p}$. 275-292. In P. Strauss and S. Wilson (ed.), The eukaryotic nucleus: molecular structure and macromolecular assemblies. The Telford Press, Caldwell, N.J.

48. Ray, B. K., T. G. Lawson, J. C. Kramer, M. H. Cladaras, J. A. Grifo, R. D. Abramson, W. C. Merrick, and R. T. Thach. 1985. ATP-dependent unwinding of messenger RNA structure by eukaryotic initiation factors. J. Biol. Chem. 260:7651-7658.

49. Reynolds, P., D. Higgins, L. Prakash, and S. Prakash. 1985. Nucleotide sequence of the RAD3 gene of Saccharomyces cerevisiae: a potential adenine nucleotide binding amino acid sequence and a nonessential acidic terminal region. Nucleic Acids Res. 13:2357-2372.

50. Rose, M., and D. Botstein. 1983. Construction and use of gene fusions to lacZ ( $\beta$-galactosidase) that are expressed in yeast. Methods Enzymol. 101:167-180.

51. Salvato, M. S., and E. M. Shimomaye. 1989. The completed sequence of lymphocytic choriomeningitis virus reveals a unique RNA structure and a gene for for a zinc finger protein. Virology 173:1-10.

52. Sanger, F., S. Nicklen, and A. R. Coulson. 1977. DNA sequencing with chain-terminating inhibitors. Proc. Natl. Acad. Sci. USA 74:5463-5467.

53. Schatz, D. G., M. A. Oettinger, and D. Baltimore. 1989. The V(D)J recombination activating gene, RAG-1. Cell 59:10351048.

54. Schiestl, R. H., and T. D. Petes. 1991. Integration of DNA fragments by illegitimate recombination in Saccharomyces cerevisiae. Proc. Natl. Acad. Sci. USA 88:7585-7589.

55. Sherman, F., G. R. Fink, and J. B. Hicks. 1986. Methods in yeast genetics: a laboratory manual. Cold Spring Harbor Laboratory, Cold Spring Harbor, N.Y.

56. Streisinger, G., Y. Okada, J. Emrich, J. Newton, A. Tsugita, E. Terzaghi, and M. Inouye. 1966. Frameshift mutations and the genetic code. Cold Spring Harbor Symp. Quant. Biol. 31:77-84.

57. Sung, P., D. Higgins, L. Prakash, and S. Prakash. 1988. Mutation of lysine- 48 in the yeast RAD3 protein abolishes its ATPase and DNA helicase activities but not its ability to bind ATP. EMBO J. 7:3263-3269.

58. Sung, P., L. Prakash, S. W. Matson, and S. Prakash. 1987. RAD3 protein of Saccharomyces cerevisiae is a DNA helicase Proc. Natl. Acad. Sci. USA 84:8951-8955.

59. Sung, P., L. Prakash, S. Weber, and S. Prakash. 1987. The RAD3 gene of Saccharomyces cerevisiae encodes a DNAdependent ATPase. Proc. Natl. Acad. Sci. USA 84:6045-6049.

60. Sung, P., S. Prakash, and L. Prakash. 1988. The RAD6 protein of Saccharomyces cerevisiae polyubiquitinates histones, and its acidic domain mediates this activity. Genes Dev. 2:1476-1485.

61. Tagawa, M., T. Sakamoto, K. Shigemoto, H. Matsubara, Y. Tamura, T. Ito, I. Nakamura, A. Okitsu, K. Imai, and $M$. Taniguchi. 1990. Expression of a novel DNA-binding protein with zinc finger structure in various tumor cells. J. Biol. Chem. 265:20021-20026.

62. Takahashi, M., Y. Inaguma, H. Hiai, and F. Hirose. 1988 Developmentally regulated expression of a human "finger"containing gene encoded by the 5 ' half of the ret transforming gene. Mol. Cell. Biol. 8:1853-1856.

63. Tamkun, J. W., R. Deuring, M. P. Scott, M. Kissinger, A. M. Pattatucci, T. C. Kaufman, and J. A. Kennison. 1992. brahma: a regulator of Drosophila homeotic genes structurally related to the yeast transcriptional activator SNF2/SWI2. Cell 68:561-572.

64. Tautz, D. 1990. Genomic fingerprinting goes simple. BioEssays 12:44-46.

65. Tautz, D., and M. Renz. 1984. Simple sequences are ubiquitous repetitive components of eukaryotic genomes. Nucleic Acids Res. 12:4127-4138.

66. Thiem, S. M., and L. K. Miller. 1989. A baculovirus gene with a novel transcription pattern encodes a polypeptide with a zinc finger and a leucine zipper. J. Virol. 63:4489-4497.

67. Turner, R., and R. Tjian. 1989. Leucine repeats and an adjacent 
DNA binding domain mediate the formation of functional cFoscJun heterodimers. Science 243:1689-1694.

68. Van Stratten, F., R. Muller, T. Curran, C. Van Beveren, and I. M. Verma. 1983. Complete nucleotide sequence of a human c-onc gene: deduced amino acid sequence of the human c-fos protein. Proc. Natl. Acad. Sci. USA 80:3183-3187.

69. Walker, J. E., M. Saraste, M. J. Runswick, and N. J. Gay. 1982. Distantly related sequences in the $\alpha$ - and $\beta$-subunits of ATP synthase, myosin, kinases and other ATP-requiring enzymes and a common nucleotide binding fold. EMBO J. 1:945-951.

70. Walmsley, R. M., J. W. Szostak, and T. D. Petes. 1983. Is there left-handed DNA at the ends of yeast chromosomes? Nature (London) 302:84-86.

71. Weber, J. L., and P. E. May. 1989. Abundant class of human DNA polymorphisms which can be typed using the polymerase chain reaction. Am. J. Hum. Genet. 44:388-396. 